International Journal of Food Science, Nutrition and Dietetics (IJFS)

ISSN 2326-3350

\title{
A Review on the Biochemical, Antimicrobial and Organoleptic Studies on the Germination Profile of Finger Millet (Eleusine coracana)
}

Ashwini G.Rane ${ }^{1 *}$, Jyoti D.Vora ${ }^{2}$, Priyanka ${ }^{1}$

${ }^{1}$ Department of Biochemistry \& Food Science and Quality Control, Ramnarain Ruia College, Matunga, Mumbai, India.

${ }^{2}$ Head, Department of Biochemistry \& Food Science and Quality Control, Ramnarain Ruia College, Matunga, Mumbai, India.

\begin{abstract}
Finger millets (or ragi) are cereals and the staple food of the millions residing in the arid and semi-arid tropics of the world. The grains of finger millets, being nutritionally superior to wheat provide Carbohydrates, dietary fibers, minerals and vitamins to poorest of the poor where the need is essential. Finger millet can be regarded as a functional food, to be taken as part of the usual diet in order to have beneficial effects that go beyond basic nutritional function, thus helping to reduce the risk of obesity, malnutrition, and premature aging. An important factor of the functional food which is required to reduce the risk of chronic illnesses is 'proper intake and antibacterial activity'. Antibacterial is used to treat bacterial infections, Germinated finger millet seeds extract (12hour sample) has a bactericidal property against Escherichia coli and can be consumed for management of infectious diarrhoea. However prolonged use of certain antibacterial can decrease the number of gut flora, which may have a negative impact on health. Results indicate that potential exists to utilize finger millet as an alternative natural antioxidant and food preservative. Sensory evaluation was carried out to project the organoleptic appeal, which proved that ragi sample was very well accepted.
\end{abstract}

Keywords: Finger Millet; Functional Food; Organoleptic Appeal; Antibacterial.

\section{*Corresponding Author:}

Ashwini G.Rane

Department of Biochemistry \& Food Science and Quality Control, Ramnarain Ruia College, Matunga, Mumbai, India.

Tel: +91-7506060997

E-mail: ashwinig_rane@hotmail.com

Received: April 12, 2014

Accepted: June 03, 2014

Published: June 12, 2014

Citation: Ashwini G.Rane, Jyoti D.Vora, Priyanka J (2014) A Review on the Biochemical, Antimicrobial and Organoleptic Studies on the Germination Profile of Finger Millet (Eleusine coracana). Int J Food Sci Nutr Diet. 3(6), 129-133. doi: http:/ / dx.doi.org/10.19070/2326-3350-1400025

Copyright: Ashwini G.Rane ${ }^{\mathcal{C}}$ 2014. This is an open-access article distributed under the terms of the Creative Commons Attribution License, which permits unrestricted use, distribution and reproduction in any medium, provided the original author and source are credited.

\section{Introduction}

Finger millet is an annual plant widely grown as a cereal in the semi-arid parts of the world. In India it is cultivated over an area of 2.65 million hectares with total production of about 2.9 million tonnes. The state of Karnataka is a leading producer accounting for $58 \%$ of India's finger millet production. Millets, being less expensive compared to cereals and the staple for the poorer sections of population, could be the choice for nutritional contents. It is a tufted crop growing to a height of $30-150 \mathrm{~cm}$ and maturing in 75-160 days. Leaves are narrow, grass-like and capable of producing many tillers and nodal branches. The panicle consists of a group of digitally arranged spikes often referred as 'fingers'. Grain is oblong to round and oval, reddish brown in colour with the grain surface finely corrugated. The crop is of tropical and subtropical climate it can be grown successfully from sea level to an altitude of 1800 meters on hill slopes as well as in plains. Finger millet can be grown on a wide range of soil from poor to very fertile soils. It thrives best in well drained loam to light red loam and sandy loam soils of good fertility.

\section{Materials and Methods}

The proximate principles of finger millet (Eleusine coracana) seeds were analyzed in the present study. Six samples with $0 \mathrm{hr}, 4 \mathrm{hr}$, $6 \mathrm{hr}, 8 \mathrm{hr}, 12 \mathrm{hr}, 24 \mathrm{hr}$ of sprouting were taken and compared with Wheat sample. Fresh samples were taken for proximate principles and mineral analysis daily.

\section{Moisture and mineral analysis}

All the finger millet samples were tested for moisture analysis by hot air oven and mineral analysis by ashing method

Total carbohydrates by anthrone method: Total carbohydrates of each sample were analyzed colorimetrically using anthrone reagent: Dissolve $200 \mathrm{mg}$ anthrone in $100 \mathrm{ml}$ of ice cold $95 \% \mathrm{H}_{2} \mathrm{SO}_{4}$. Prepare fresh before use. Standard Glucose stock, $2.5 \mathrm{~N} \mathrm{HCl}$. The absorbance was read at $630 \mathrm{~nm}$.

Dietary fibres : Dietary fibers were estimated using Petroleum ether, Alcohol, Sulphuric acid solution: $1.25 \mathrm{~g}$ concentrated sulphuric acid diluted to $100 \mathrm{ml}$, Sodium hydroxide solution: $1.25 \mathrm{~g}$ sodium hydroxide in $100 \mathrm{ml}$ distilled water

Vitamin $C$ by using Harris-ray method : Vitamin C in all the samples were estimated using 2,6 dichlorophenol indophenols blue solution, Glacial acetic acid, Standard Vitamin C solution $(0.02 \mathrm{mg} / \mathrm{ml})$, Working Vitamin C solution, Meta phosphoric acid 
Phosphorus by Fiske-Subbarow method: Phosphorus content was estimated using Acid molybdate reagent, 1,2,4 aminonaphthosulphonic acid $(0.25 \%)$, Stock standard phosphorus solution, Dissolve $0.351 \mathrm{mg}$ of pure potassium dihydrogen phosphate in water, add $10 \mathrm{ml}$ of $\mathrm{NH}_{2} \mathrm{SO}_{4}$ and make the volume to 1 liter, Working standard phosphorus solution $(0.008 \mathrm{mg} / \mathrm{ml})$

Calcium by Ethylenediamine tetra acetic acid method: Calcium content was estimated using $0.01 \mathrm{M}$ EDTA-0.930g EDTA in $250 \mathrm{ml}$ distilled water, Ammonia buffer $\left(\mathrm{NH}_{3}: \mathrm{NH}_{4} \mathrm{OH}\right.$ at ph10), Eriochrome black $\mathrm{t}$ indicator

\section{Antimicrobial activity}

Sample preparation : 10gms was weighed and grinded in mortar pestle using chilled distilled water.Filter the seeds and measure the volume of chilled distilled water added after extraction. The extract was autoclaved and refrigerated at $4^{\circ} \mathrm{C}$.Extract is then used for determination of Minimum inhibitory concentration.

Minimum Inhibitory Concentration: Minimum Inhibitory Concentration was determined using Stock-Autoclaved non germinated(0hrs) and germinated(12hrs) finger millet seeds,Diluent-Sterile Nutrient Broth,Culture-24hrs old E.coli cul-

Figure 1. The study showed an increase in Carbohydrates, the major source of biological energy which is obtained through oxidation in the tissue. This information supports that finger millets are healthy sources of carbohydrates for persons with insulin sensitivity or diabetes.

CARBOHYDRATE CONTENT

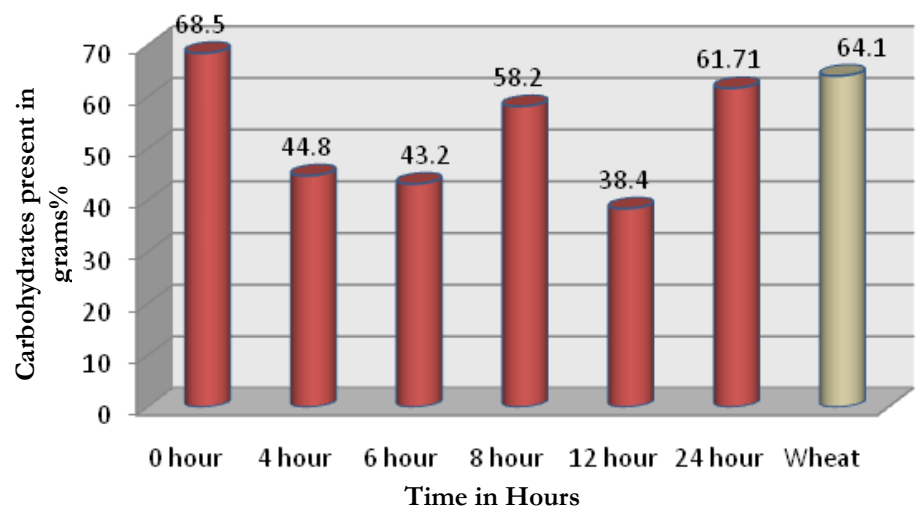

Figure 3. Finger millet is rich in Calcium and phosphorus which helps in development of bones in growing children and in maintenance of bone health in adults. It may also keep diseases such as osteoporosis at bay and could reduce risk of fracture.

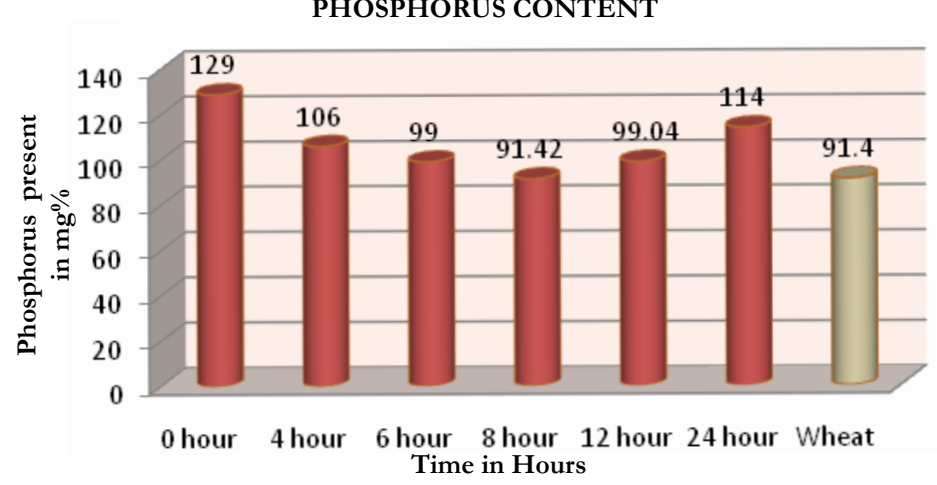

ture, Incubation time-Incubated at $37^{\circ} \mathrm{C}$ for $24 \mathrm{hrs}$.

Extraction of DNA by Phenol Chloroform method: Extraction was carried out using Sterile phosphate buffer ( $\mathrm{pH}$ 7.0), Lysis buffer, Proteinase K $(20 \mathrm{mg} / \mathrm{ml})$, Absolute ethanol, 70\% ethanol, Phenol: Chloroform:Isoamly alcohol (25:24:1), T.E (Tris- EDTA) buffer

Quantitative analysis of DNA by Agarose gel electrophoresis : Qualitative analysis of DNA using Agarose Gel Electrophoresis was done using Agarose, 1X TBE buffer, $10 \mathrm{mg} / \mathrm{ml}$ Ethidium bromide, 6X gel loading dye

Real time PCR: Polymerase Chain Reaction was performed using $\mathrm{SyBr}$ Green Master Mix, Primers, MilliQ

\section{Results and Discussions}

The proximate analysis and antimicrobial activity reveal that finger millets were found to contain higher amounts of carbohydrates, dietary fibers, calcium, phosphorus and vitamin $\mathrm{C}$ when compared with wheat.

\section{Conclusions}

Figure 2. Finger millet is rich in Calcium and phosphorus which helps in development of bones in growing children and in maintenance of bone health in adults. It may also keep diseases such as osteoporosis at bay and could reduce risk of fracture.

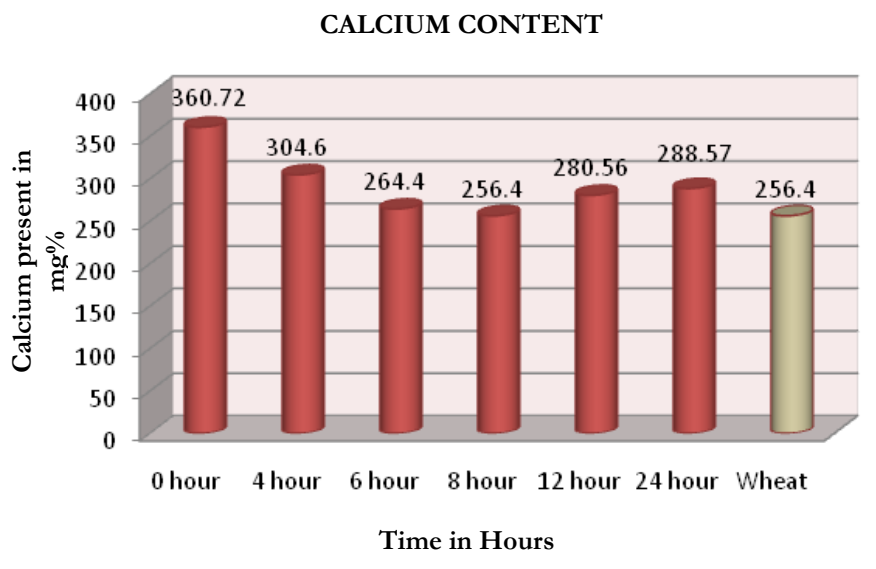

Figure 4. The high fiber in the finger millet may enhance digestibility and also aid the peristaltic movement of the intestinal tract.

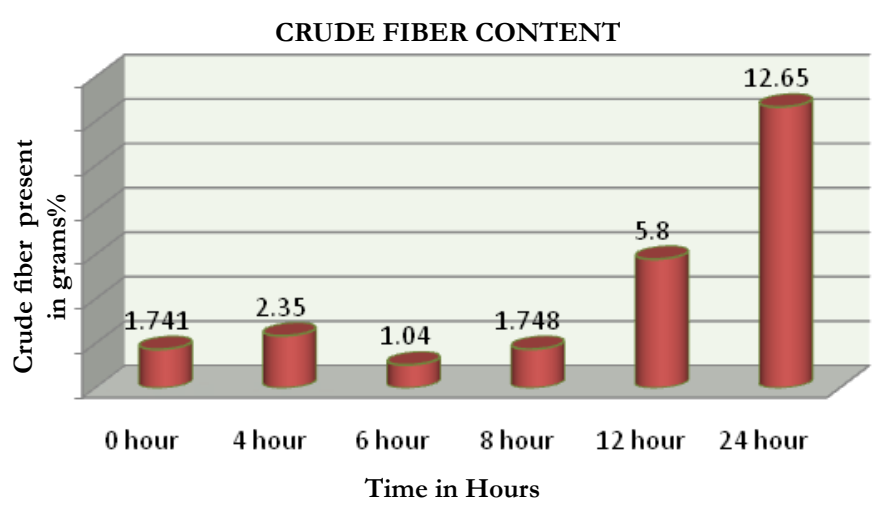


Figure 5. Due to high Vitamin C content that is antioxidants may help fight off free radicals in the body, warding off inflammation, infections.

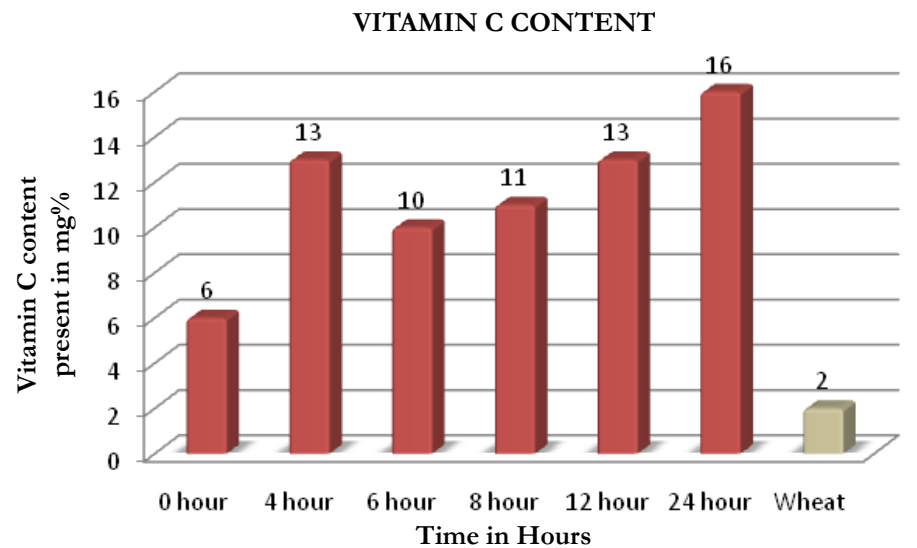

Table $1 \& 2$. From antimicrobial studies The MIC for non-germinated finger millet (0hrs) was found to be $110 \mathrm{mg} / \mathrm{ml}$. The MIC for germinated finger millet (12hrs) was found to be $125 \mathrm{mg} / \mathrm{ml}$.

Table 1. Non-germinated finger millet seeds

\begin{tabular}{|l|l|}
\hline Concentration & Inhibition \\
\hline 22 & +++++ \\
\hline 44 & ++++ \\
\hline 66 & +++ \\
\hline 88 & ++ \\
\hline 110 & - \\
\hline Positive Control & + \\
\hline Negative Control & - \\
\hline Medium Control & - \\
\hline Abbreviation (+) - Growth, (-) -No Growth
\end{tabular}

Table 2. Germinated finger millet seeds (12hours)

\begin{tabular}{|l|l|}
\hline Concentration & Inhibition \\
\hline 25 & +++++ \\
\hline 50 & ++++ \\
\hline 75 & +++ \\
\hline 100 & ++ \\
\hline 125 & - \\
\hline Positive Control & + \\
\hline Negative Control & - \\
\hline Medium Control & - \\
\hline Abbreviation (+) - Growth, (-) -No Growth
\end{tabular}

Figure 6. DNA from the MIC sample (germinated and non- germinated finger millet) was extracted using Phenol Chloroform method. The presence of genomic DNA was confirmed by running DNA sample on 1\% agarose gel at 50 to 60 Volts, until the dye front approximately ran $75-80 \%$ of the gel. The DNA bands obtained was observed using U.V transilluminator.

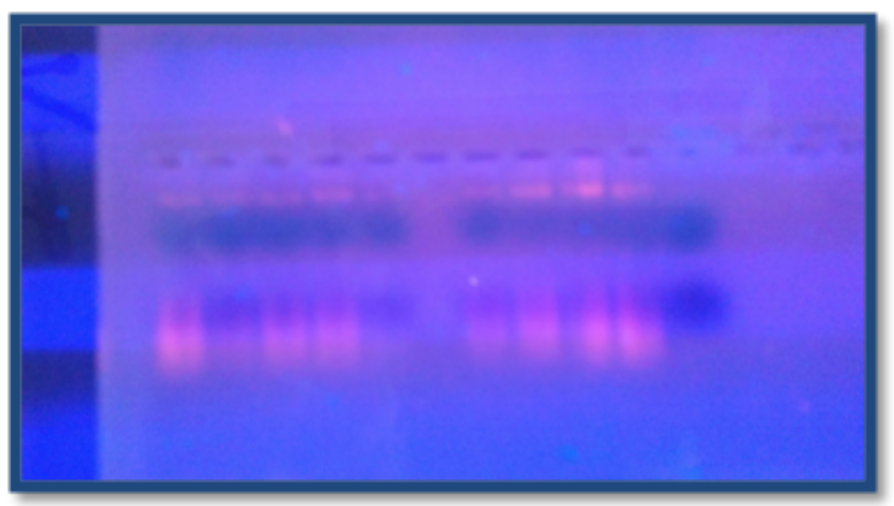


Figure7, 8,9,10 and table 3 showing Real time PCR results From sensory Evaluation (Figure 11, 12, 13)

Figure 7. Endogenous control gene

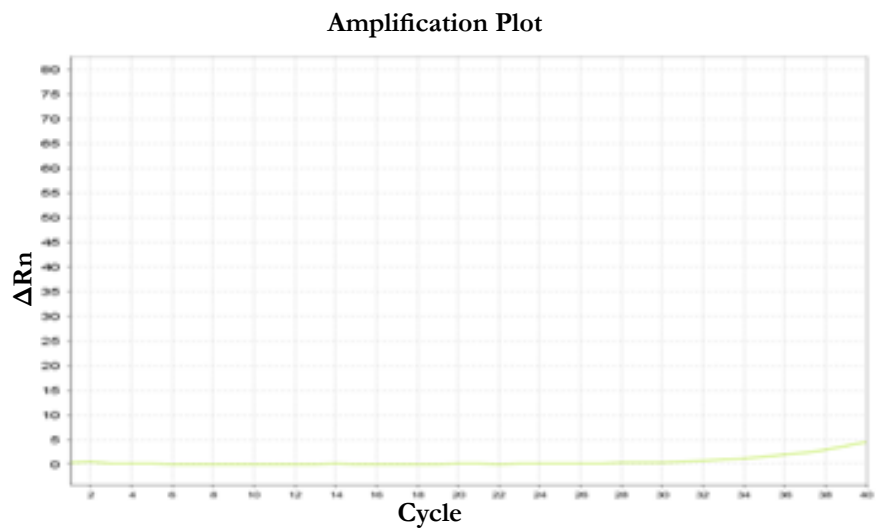

Figure 8. Reference gene

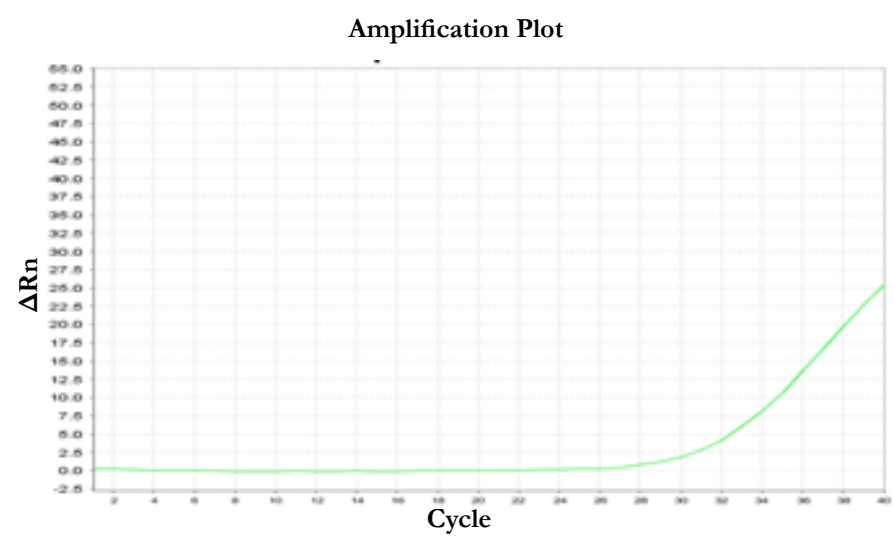

Samples treated with germinated finger millet seeds (12 hours)
Figure 10

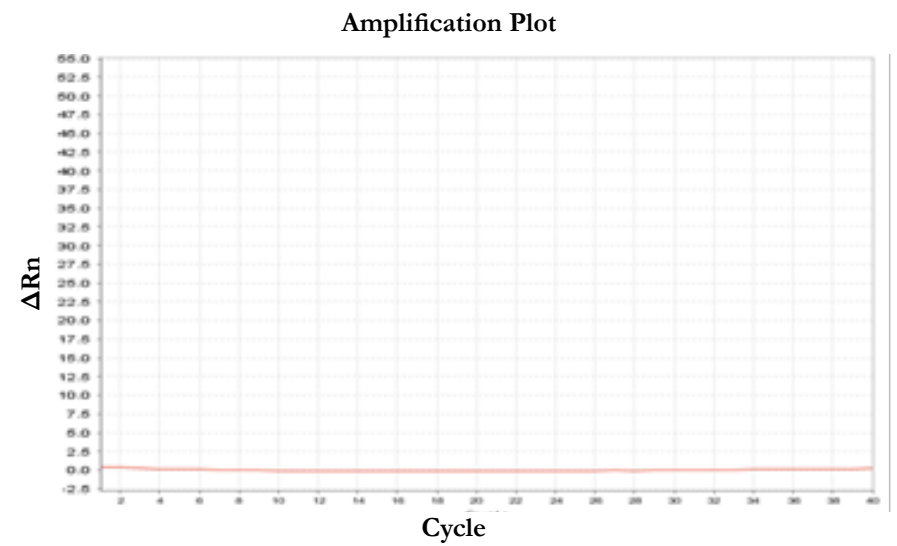

Figure 11. Overall Preference

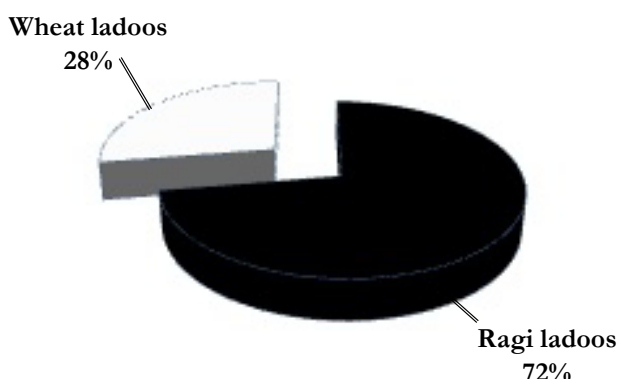

Figure 13. VFM of the Product

Figure 12. Preference of the subject to buy the product if

\begin{tabular}{|l|l|l|}
\hline Sample & $\begin{array}{l}\mathrm{Ct} \\
\text { (reference gene) }\end{array}$ & $\begin{array}{l}\mathrm{Ct} \\
\text { (endogenous control }\end{array}$ \\
\hline Untreated & 10.78 & 10.59 \\
\hline $\begin{array}{l}\text { Treated } \\
\text { (non-germinated) }\end{array}$ & 27.58 & 31.06 \\
\hline $\begin{array}{l}\text { Treated } \\
\text { (germinated) }\end{array}$ & Undetermined & Undetermined \\
\hline
\end{tabular}

\section{commercially available}
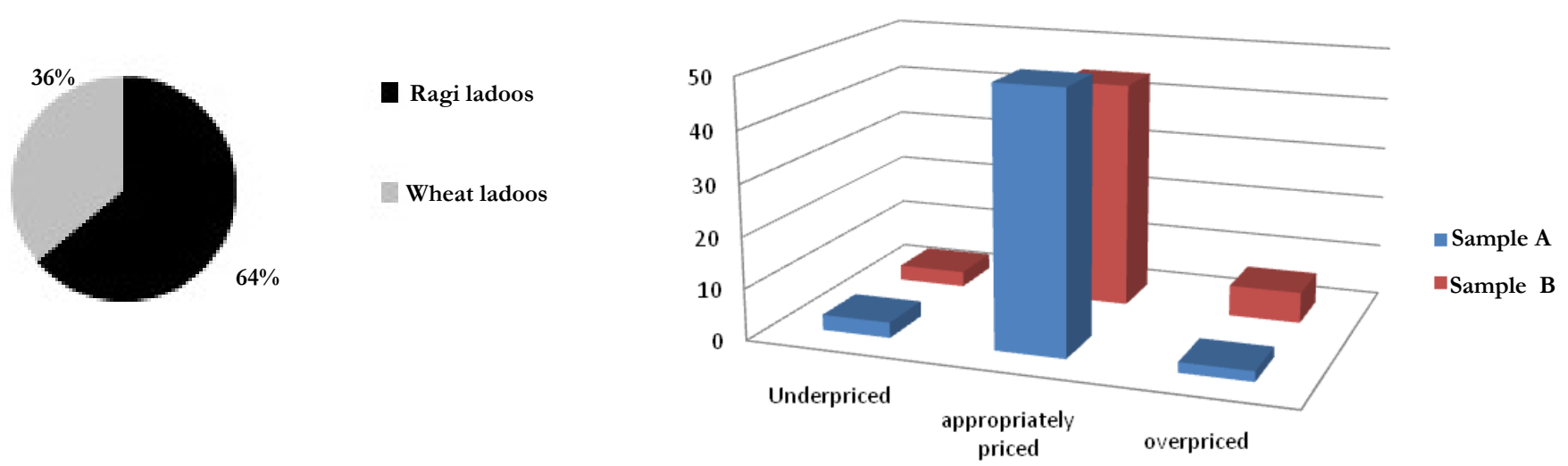
Finger millet occupy an important place in the world food and economy.They can adapt themselves to marginal soils and varied environmental conditions.Finger millets are the staple diet for nearly $1 / 3$ rd of the world's population.By considering these points an evaluation of proximate principles, Antimicrobial, and organoleptic studies was conducted.Finger millet contain large quantities of all the essential aspects and posses antibacterial activity which prevent deterioration of human health.

\section{References}

[1]. Sadasivam S, Manickam A (1996) Biochemical methods, 2nd edn. New Age International Publication, p.8-9,20-21,56-58,184-187

[2]. M.Sc. Protocol Committee Laboratory Manual T. Y BSc. Biochemistry \& MSc. Department Of Biochemistry and Food Science \& Quality Control, p. 8,270

[3]. C. Kothari (1985) Research Methodology: Methods and Techniques, New Age International Publication 2nd Edn,p.233-246

[4]. Internet: TNAU AGRITECH PORTAL, Agriculture downloaded from http://agritech.tnau.ac.in/agriculture/agri costofcultivation ragi.html

[5]. Cereals and pulses downloaded from http://database.prota.org/PROTAhtml/Eleusine\%20coracana_En.htm

[6]. Real-time polymerase chain reaction downloaded from http://en.wikipedia. org/wiki/Realtime_polymerase_chain_reaction\#Basic_principles

[7]. Eleusine coracana,nutrition downloaded from http://en.wikipedia.org/wiki/ Eleusine coracana\#Nutrition

[8]. Kissan Kerala,crop information downloaded from http://www.kissankerala, net/kissan/kissancontents/ragi.htm

[9]. SIKKIM AGRISNET,Nutrient Requirement Downloaded from http:// www.sikkimagrisnet.org/General/en/fingermillet_Nutrient_Management. aspx

[10]. Veg Weight loss diets,Ragi flour nutritional value and benefits downloaded from http://vegweightlossdiets.com/good-diet/ragi-flour-nutritional-valueand-benefits/

[11]. Shobana S, Krishnaswamy K, Sudha V, Malleshi NG, Anjana RM, et al .Finger millet(Ragi,Eleusine coracana L): a review of its nutritional properties,processing,and plausible health benefits. Madras Diabetes Research Foundation, Gopalapuram, Chennai, India. 